\title{
PENERAPAN MODEL PEMBELAJARAN GUIDED NOTE TAKING UNTUK MENINGKATKAN AKTIVITAS BELAJAR SEJARAH DI SMA NEGERI 3 LUBUKLINGGAU
}

\author{
Diana Agusfina1, Ira Miyarni Sustianingsih ${ }^{2}$, Risa Marta Yati ${ }^{2}$ \\ 1) Alumni Program Studi Pendidian Sejarah, STKIP PGRI Lubuklinggau, Indonesia \\ 2) Program Studi Pendidikan Sejarah, STKIP PGRI Lubuklinggau, Indonesia \\ Corresponding Email: dianaagusfina@gmail.com
}

\begin{abstract}
This study aims to determine the effect of the Guided Note Taking learning model on the improvement of students' historical learning activities at SMA Negeri 3 Lubuklinggau. The research method used is a quantitative method. The sample of this study was 33 students of class X IPS 3. Data collection techniques using observation sheet instruments. The data obtained were analyzed using relative frequency percentages. The results showed that the Guided Note Taking learning model applied in the history learning process in class X IPS 3 of SMA Negeri 3 Lubuklinggau was able to increase student learning activities. This is evidenced by the value of the percentage of student learning activities that increased from $81.72 \%$ at the first meeting to $91 \%$ at the second meeting or increased from the good to very good category.
\end{abstract}

Keywords: Guided Note Taking, Learning Activities, Learning Model

\begin{abstract}
Abstrak
Penelitian ini bertujuan untuk mengetahui pengaruh model pembelajaran Guided Note Taking terhadap peningkatan aktivitas belajar sejarah siswa di SMA Negeri 3 Lubuklinggau. Metode penelitian yang digunakan adalah metode kuantitatif. Sampel penelitian adalah siswa kelas X IPS 3 yang berjumlah 33 orang. Teknik pengumpulan data menggunakan intrumen lembar observasi. Data yang diperoleh dianalisis dengan menggunakan persentase frekuensi relatif. Hasil penelitian menunjukkan bahwa model pembelajaran Guided Note Taking yang diterapkan dalam proses pembelajaran sejarah di kelas X IPS 3 SMA Negeri 3 Lubuklinggau mampu meningkatkan aktivitas belajar siswa. Hal ini dibuktikan dengan nilai persentase aktivitas belajar siswa yang mengalami peningkatan dari $81,72 \%$ pada pertemuan pertama menjadi $91 \%$ di pertemuan kedua, atau meningkat dari kategori baik menjadi sangat baik.
\end{abstract}

Kata Kunci: Guided Note Taking, Aktivitas Belajar, Model Pembelajaran 


\section{PENDAHULUAN}

Pendidikan merupakan suatu interaksi antara guru dan siswa yang dapat menunjang pengembangan manusia seutuhnya yang berorientasi pada nilai-nilai serta pelestarian dan pengembangan kebudayaan yang berhubungan dengan usaha-usaha pengembangan manusia. Sumiati dan Asra (2009: 65) memandang pendidikan sebagai salah satu faktor utama yang menentukan pertumbuhan ekonomi melalui peningkatan produktivitas tenaga kerja terdidik. Bahkan pendidikan juga dipandang memiliki peranan penting dalam menjamin perkembangan dan keberlangsungan bangsa.

Menurut Ulhaq, (2017: 114), kualitas pendidikan dapat diketahui dari proses dan produk pendidikan itu sendiri. Pendidikan dikatakan berkualitas apabila penyelenggaraan pembelajaran berjalan efektif dan efisien dengan melibatkan semua komponen-komponen pendidikan, mulai dari tujuan pembelajaran, guru dan peserta didik, bahan pelajaran, strategi atau metode pembelajaran, alat dan sumber belajar, serta evaluasi. Komponen-komponen tersebut terlibat secara langsung tanpa menonjolkan salah satu komponen saja, tetapi semua komponen diberdayakan secara bersama-sama.

Pada jenjang Sekolah Menengah Atas (SMA), mata pelajaran sejarah diberikan sebagai bagian integral dari mata pelajaran Ilmu Pengetahuan Sosial (IPS). Hal ini disebabkan karena bidang studi IPS di jenjang SMA merupakan salah satu mata pelajaran terpadu yang terdiri dari beberapa cabang ilmu, yaitu sosiologi, ekonomi, geografi dan sejarah. Menurut Slameto (2010: 89), fungsi dari diadakannya mata pelajaran sejarah di SMA adalah sebagai ilmu pengetahuan untuk mengembangkan kemampuan dan sikap rasional dalam menghadapi kenyataan atau permasalahan sosial, serta perkembangan masyarakat Indonesia dan masyarakat dunia di masa lampu, masa kini dan masa mendatang. Namun, pola pembelajaran yang dikembangkan oleh guru-guru sejarah selama ini cenderung bersifat teks book oriented yang hanya memindahkan pengetahuan secara utuh dari kepala guru ke kepala siswa. Pola pembelajaran seperti ini menyebabkan siswa jenuh karena mereka tidak diajarkan berpikir logis, hanya mementingkan pemahaman dan hafalan sehingga kejenuhan akan membuat siswa kurang fokus dalam belajar dan tentunya mempengaruhi aktivitas belajar (Erniwati, 2015: 1-2).

Kondisi pembelajaran sejarah yang membosankan juga ditemukan di SMA Negeri 3 Lubuklinggau. Berdasarkan hasil observasi awal yang dilakukan peneliti pada tanggal 10 Januari 2019 diperoleh informasi bahwa permasalahan yang terjadi dalam proses pembelajaran sejarah di kelas X IPS SMA Negeri 3 Lubuklinggau adalah kurangnya peran siswa dalam mengikuti kegiatan pembelajaran. Siswa terlihat kurang memiliki keinginan untuk terlibat secara aktif dalam proses pembelajaran dan hanya menunggu materi yang disampaikan guru tanpa ada inisiatif untuk mencari dan menggali informasi secara mandiri atau kelompok sebelum materi disajikan. Hal ini mencerminkan betapa minimnya aktivitas belajar siswa di kelas X IPS SMA Negeri 3 Lubuklinggau.

Menurut Fitriana (2014: 47), proses pembelajaran sejarah seharusnya diarahkan kepada kegiatan yang mendorong siswa belajar aktif, baik secara fisik, sosial maupun psikis dalam memahami konsep. Oleh karena itulah guru sejarah hendaknya menggunakan model pembelajaran yang dapat merangsang aktivitas siswa sehingga dapat menimbulkan menimbulkan rasa senang dan antusias dalam belajar. Dengan menggunakan model pembelajaran yang mampu merangsang aktivitas siswa, maka pemahaman siswa terhadap konsep sejarah akan semakin meningkat.

Salah satu model pembelajaran yang dapat merangsang aktivitas belajar siswa adalah model pembelajaran Guided Note Taking. Menurut Suprijono (2010: 105), model pembelajaran Guided Note Taking adalah model pembelajaran yang dapat membantu siswa dalam membuat catatan-catatan mengenai materi pelajaran yang 
disampaikan oleh guru dengan menggunakan metode ceramah. Model pembelajaran bertujuan agar metode ceramah yang dikembangkan oleh guru mendapat perhatian siswa, terutama pada kelas yang jumlah siswanya cukup banyak.

Model pembelajaran Guided Note Taking dilaksanakan dengan cara memberikan panduan kepada siswa yang berisi ringkasan poin-poin utama dari materi pelajaran yang disampaikan guru dengan metode ceramah. Namun, sebagian dari poin-poin yang dianggap penting harus dikosongkan sehingga terdapat ruang-ruang kosong dalam panduan tersebut. Jika panduan memuat istilah dengan pengertiannya, maka kosongkan beberapa istilah dan defenisinya. Jika poin-poin utamanya terdiri dari beberapa pertanyaan, guru dapat mengosongkan sebagian dari pertanyaan tersebut. Guru juga dapat menghilangkan beberapa kata kunci dari sebuah paragraf yang dimuat dalam panduan. Selanjutnya, guru membuat bahan ajar (handout) yang di dalamnya tercantum sub topik dari materi pelajaran. Beri tempat kosong yang cukup agar siswa dapat membuat catatan di dalamnya. Setelah membagikan handout, guru meminta siswa untuk membacakan hasil catatannya dan guru memberikan klarifikasi (Silberman, 2009: 46).

Berdasarkan pendapat para ahli yang diuraikan di atas dapat dikatakan bahwa model pembelajaran Guided Note Taking mampu meningkatkan aktivitas siswa dalam bentuk interaksi antarsiswa maupun siswa dengan guru dalam proses pembelajaran. Model pembelajaran ini memungkinkan siswa belajar lebih aktif karena memberikan kesempatan mengembangkan diri, fokus pada handout dan materi ceramah, serta diharapkan mampu merangsang siswa untuk memecahkan masalah sendiri dengan menemukan (discovery) dan bekerja sendiri. Oleh karenanya, penelitian ini akan mengkaji apakah model pembelajaran Guided Note Taking dapat meningkatkan aktivitas belajar sejarah siswa di SMA Negeri 3 Lubuklinggau.

\section{METODE PENELITIAN}

Penelitian ini menggunakan metode kuantitatif dengan desain eksperimen one shot-case study. Penelitian dilakukan di SMA Negeri 3 Lubuklinggau, Sumatera Barat. Penelitian berlangsung sejak 25 Juli sampai 25 Agustus 2019. Populasi penelitian adalah siswa kelas $\mathrm{X}$ yang terdiri dari empat kelas dengan jumlah siswa mencapai 142 orang. Pengambilan sampel dilakukan secara acak. Hasilnya, siswa kelas X IPS 3 yang berjumlah 33 orang terpilih menjadi sampel penelitian.

Pengumpulan data menggunakan instrumen lembar observasi. Indikator aktivitas belajar dalam lembar observasi telah disesuaikan dengan model pembelajaran Guided Note Taking, seperti mencermati panduan yang berisi ringkasan poin-poin utama dari materi pelajaran, memperhatikan materi pelajaran yang disampaikan guru dengan strategi ceramah, mengisi poin-poin penting dalam handout dan membacakan hasil catatan. Kegiatan observasi dilaksanakan sewaktu proses pembelajaran dengan model Guided Note Taking sedang berlangsung di kelas X IPS 3 SMA Negeri 3 Lubuklinggau.

Instrumen penelitian divalidasi dengan menggunakan validitas isi. Menurut Arikunto (2010: 87), validitas isi menunjukkan pada pengertian apakah alat tes mempunyai kesejajaran (sesuai) dengan tujuan dan deskripsi bahan pelajaran yang diajarkan. Jika butir-butir tes secara jelas dimaksudkan untuk mengukur tujuantujuan tertentu dan bersifat mewakili bahan yang diajarkan, tes tersebut dikatakan memiliki kesahian isi. Kriteria kelayakan tes menunjukkan pada kesesuaian antara tujuan dan bahan dalam alat tesnya, tak lain adalah jenis kesahihan isi. Untuk mengetahui apakah suatu tes telah mempunyai kesahian isi, alat tes tersebut harus dikonsultasikan dan dievaluasi kepada orang yang lebih ahli dalam bidang yang bersangkutan (expert judgement). Oleh karenanya, instrumen penelitian ini telah divalidasi oleh dosen ahli di STKIP-PGRI Lubuklinggau. 
Data aktivitas belajar siswa yang diperoleh dari lembar observasi kemudian dianalisis dengan menggunakan rumus NP (Nilai Persen) yang disesuaikan dengan interpretasi nilai presentase aksitivitas belajar siswa yang dibagi ke dalam beberapa kategori.

\section{HASIL DAN PEMBAHASAN}

Penelitian diawali dengan memberikan perlakuan (treatment) menggunakan model pembelajaran Guided Note Taking kepada siswa kelas $X$ IPS 3 SMA Negeri 3 Lubuklinggau. Model pembelajaran Guided Note Taking digunakan untuk membahas materi pelajaran mengenai "sejarah sebagai peristiwa, kisah, ilmu dan seni". Langkah-langkah model pembelajaran Guided Note Taking yang diterapkan sesuai dengan pendapat Zaini (2008: 32), yaitu dimulai dari memberikan siswa panduan yang berisi ringkasan poin-poin utama dari materi pelajaran yang disampaikan dengan metode ceramah, mengkosongkan bagian-bagian yang dianggap penting sehingga terdapat ruang-ruang kosong dalam panduan, memberikan suatu istilah dengan pengertiannya, mengosongkan istilah atau definisinya, mengosongkan beberapa pertanyaan jika bagian-bagian utamanya terdiri dari beberapa pertanyaan, menghilangkan beberapa kata kunci dari sebuah paragraf. Kemudian guru membuat handout yang di dalamnya tercantum sub topik dari materi pembelajaran. Memberi tempat kosong yang cukup di dalam handout agar siswa dapat mengisi bagian yang dikosongkan tersebut. Selanjutnya, guru membagikan handout kepada siswa dan meminta siswa untuk membacakan hasil catatannya yang diisi di dalam handout. Setelah itu, guru memberikan klarifikasi.

Pada saat proses pembelajaran sedang berlangsung, peneliti membuat penilaian terhadap aktivitas belajar siswa. Penilaian dilakukan dalam dua kali pertemuan yang sama-sama menggunakan model pembelajaran Guided Note Taking. Hasil penilaian terhadap aktivitas belajar siswa pada pertemuan pertama disajikan dalam tabel 1, sedangkan hasil penilaian pada pertemuan kedua dapat dilihat pada tabel 2 .

Tabel 1 menunjukkan bahwa aspek mencermati panduan yang berisi ringkasan poin-poin utama dari materi pelajaran yang disampaikan guru memperoleh nilai persentase sebesar $86 \%$ dengan kategori sangat baik, aspek memperhatikan pembicaraan yang terjadi dalam kelompok pada saat mengisi handout memperoleh nilai persentase sebesar $79 \%$ dengan kategori baik, aspek mengisi bagian yang dikosongkan dengan tanda titik-titik yang ada di handout memperoleh nilai persentase sebesar $81 \%$ dengan kategori baik, dan aspek membacakan hasil catatan isian handout memperoleh nilai presentase sebesar $80 \%$ dengan kategori baik. Nilai persentase aktivitas belajar siswa pada pertemuan pertama mencapai $81,72 \%$ dengan kategori baik.

Tabel 2 menunjukkan bahwa aspek mencermati panduan yang berisi ringkasan poin-poin utama dari materi pelajaran yang disampaikan guru memperoleh nilai persentase sebesar $94 \%$ dengan kategori sangat baik, aspek memperhatikan pembicaraan yang terjadi dalam kelompok pada saat mengisi andout memperoleh nilai persentase sebesar 90\% dengan kategori sangat baik, aspek mengisi bagian yang dikosongkan dengan tanda titik-titik yang ada di handout memperoleh nilai persentase sebesar $90 \%$ dengan kategori sangat baik, dan aspek membacakan hasil catatan isian handout memperoleh nilai presentase sebesar $91 \%$ dengan kategori sangat baik. Nilai persentase aktivitas belajar siswa pada pertemuan kedua mencapai $91 \%$ dengan kategori sangat baik.

Hasil observasi pada pertemuan kedua memperlihatkan adanya peningkatan aktivitas belajar siswa dibandingkan dengan pertemuan pertama. Tingginya nilai persentase aktivitas belajar siswa pada pertemuan pertama dan kedua dipengaruhi oleh model pembelajaran Guided Note Taking yang membuat siswa menjadi lebih rajin dan aktif dalam mengikuti proses pembelajaran di kelas. Model pembelajaran Guided 
Note Taking mampu membantu siswa dalam menangkap ide pokok dari materi pelajaran sehingga materi lebih mudah diserap dan dipahami oleh siswa. Selain itu, model pembelajaran Guided Note Taking juga mampu meningkatkan tanggung jawab siswa, melatih keberanian siswa dalam menyimpulkan, mendefinisikan, merumuskan dan berpikir general, serta mampu melatih melatih kedisiplinan siswa sehingga proses belajar mengajar menjadi aktif dan menyenangkan.

Tabel 1. Persentase Aktivitas Belajar Siswa pada Pertemuan Pertama

\begin{tabular}{|c|l|c|c|}
\hline No & \multicolumn{1}{|c|}{ Aspek Aktivitas Belajar } & $\begin{array}{c}\text { Nilai } \\
\text { Persentase (\%) }\end{array}$ & Kategori \\
\hline 1 & $\begin{array}{l}\text { Mencermati panduan yang berisi ringkasan poin-poin } \\
\text { utama dari materi pelajaran yang disampaikan guru. }\end{array}$ & $86 \%$ & Sangat Baik \\
\hline 2 & $\begin{array}{l}\text { Memperhatikan pembicaraan yang terjadi dalam kelompok } \\
\text { pada saat mengisi handout. }\end{array}$ & $79 \%$ & Baik \\
\hline 3 & $\begin{array}{l}\text { Mengisi bagian yang dikosongkan dengan tanda titik-titik } \\
\text { yang ada di handout. }\end{array}$ & $81 \%$ & Baik \\
\hline 4 & Membacakan hasil catatan yang diisi di dalam handout. & $80 \%$ & Baik \\
\hline & Nilai Persentase & $81,72 \%$ & Baik \\
\hline
\end{tabular}

Tabel 2. Persentase Aktivitas Belajar Siswa pada Pertemuan Kedua

\begin{tabular}{|c|l|c|c|}
\hline No & \multicolumn{1}{|c|}{ Aspek Aktivitas Belajar } & $\begin{array}{c}\text { Nilai } \\
\text { Persentase (\%) }\end{array}$ & Kategori \\
\hline 1 & $\begin{array}{l}\text { Mencermati panduan yang berisi ringkasan poin-poin } \\
\text { utama dari materi pelajaran yang disampaikan guru. }\end{array}$ & $94 \%$ & Sangat Baik \\
\hline 2 & $\begin{array}{l}\text { Memperhatikan pembicaraan yang terjadi dalam kelompok } \\
\text { pada saat mengisi handout. }\end{array}$ & $90 \%$ & Sangat Baik \\
\hline 3 & $\begin{array}{l}\text { Mengisi bagian yang dikosongkan dengan tanda titik-titik } \\
\text { yang ada di handout. }\end{array}$ & $90 \%$ & Sangat Baik \\
\hline 4 & Membacakan hasil catatan yang diisi di dalam handout. & $91 \%$ & Sangat Baik \\
\hline & Nilai Persentase & $91 \%$ & Sangat Baik \\
\hline
\end{tabular}

Meskipun model pembelajaran Guided Note Taking mampu meningkatkan aktivitas belajar siswa kelas X IPS 3 SMA Negeri 3 Lubuklinggau, tapi saat model pembelajaran ini diterapkan masih terdapat beberapa hambatan yang dihadapi, yaitu beberapa siswa terlihat kesulitan dalam mengisi bagian yang dikosongkan pada lembar handout dan terlihat malu-malu dalam membacakan hasil catatannya. Hal ini dikarenakan masih kurangnya kesadaran siswa untuk bekerja sama dalam mengerjakan tugas yang diberikan guru sehingga masing-masing siswa saling mengandalkan satu sama lain. Upaya yang dilakukan untuk mengatasi masalah tersebut ialah dengan memberikan motivasi ke- pada siswa untuk lebih meningkatkan kerja sama mereka.

\section{SIMPULAN}

Peneraparan model pembelajaran Guided Note Taking dalam proses pembelajaran sejarah di kelas X IPS 3 SMA Negeri 3 Lubuklinggau mampu meningkatkan aktivitas belajar siswa. Hal ini ditunjukkan dengan tingginya nilai persentase aktivitas belajar siswa yang mencapai $81,72 \%$ pada pertemuan pertama, kemudian meningkat menjadi $91 \%$ pada pertemuan kedua. Dengan demikian, penggunaan model pembelajaran Guided Note Taking mampu membuat siswa kelas X IPS 3 SMA Negeri 3 Lubuk- 
linggau lebih rajin dan aktif dalam mengikuti pembelajaran sejarah di kelas sehingga proses pembelajaran menjadi lebih menyenangkan.

\section{REFERENSI}

Arikunto, S. (2010). Prosedur Penelitian: Suatu Pendekatan Praktik. Jakarta: Rineka Cipta.

Erniwati. (2015). Upaya Peningkatan Aktivitas Belajar Sejarah Siswa Melalui Pembelajaran Cooperatif Learning Tipe Snowball Throwing di Kelas XI IPS 3 SMA Negeri 1 Pasaman. Jurnal Educatio, 1(1), 1-12. https://doi.org/https://doi.org/10.29210/120 1523.

Fitriana, A. N. (2014). Peningkatan Aktivitas dan Hasil Belajar Siswa pada Mata Pelajaran Sejarah Melalui Model Pembelajaran Cooperative Integrated Reading and Composition. Indonesian Journal of History Education, 3(1), 46-50.

Silberman, M. L. (2009). Active Learning. Yogyakarta: Pustaka Insan Madani.

Slameto. (2010). Belajar dan Faktor-faktor yang Mempengaruhinya. Jakarta: Rineka Cipta.

Sumiati dan Asra. (2009). Metode Pembelajaran. Bandung: Wacana Prima.

Suprijono, A. (2010). Cooperative Learning. Yogyakarta: Pustaka Pelajar.

Ulhaq. (2017). Kompetensi Pembelajaran. Jakarta: Bumi Aksara.

Zaini, H. (2008). Strategi Pembelajaran Aktif. Yogyakarta: Pustaka Insan Madani. 